\title{
The lure of the local: 'News' definitions in community broadcasting
}

\section{ABSTRACT}

Journalists and media researchers globally are increasingly expressing concern about trends in the news media industry which would appear to suggest a dire future for quality journalism, and thus democracy, in many developed democratic nations. The US State of the News Media report, now produced annually, regularly reports concerns by journalists and editors-and those who study them-about decreasing investment by news corporations in quality journalism (Pew Centre, 2005; 2006; 2007; 2008). The Australian Press Council has presented its own study to mirror that of the Pew Centre in an effort to report on the Australian context (APC, 2006; 2007). The author has, with colleagues from Griffith University, conducted research into the Australian community broadcasting sector for the past nine years. The research conducted since 1999 has been broad but this article will focus on one element of the research-the news and information services of community broadcasting. The community broadcasting sector is worthy of close investigation, because it is one of the few areas of the Australian media landscape that continues to grow. Importantly, quantitative research into the community sector indicates that 57 percent of the Australian population tune in at least monthly to a community radio station-and more than one in four listen at least weekly (McNair Ingenuity, 2008, p. 4). This article investigates the nature of community news offered by the Australian community radio sector through the perspectives of journalists and producers who deliver the news, and the audiences who access it.

Keywords: alternative media, commnity broadcastng, empowerment, independent media, ethnic diversity

\section{SUSAN FORDE}

Centre for Public Culture and Ideas, Griffith University 
$\mathrm{T}$ HE AUSTRALIAN community broadcasting sector is growing at a rapid rate, and the number of community radio stations broadcasting now far outweigh the number of commercial operators. In 2009 there were 483 licensed, independent and community-owned and operated broadcasting services in Australia primarily comprised of radio, with some community television operating in five capital cities and in remote Indigenous communities (ACMA, 2008; Forde, Foxwell \& Meadows 2009, p. 21). The number of community media outlets has trebled since the early $1990 \mathrm{~s}$, and it is now far bigger than the commercial radio sector which has 274 operating licenses. Added to this, almost 98 percent of these community stations are broadcasting 24 hours a day, seven days a week - so the old notion of parttime community broadcasting, or periods of 'downtime' are well in the past. Community broadcasters are recognising, particularly in the last 10 years, that they are serious operators providing serious culture, music and-importantly for the purposes of this article-local content to their audiences.

This article focuses on the news and information services provided by the Australian community broadcasting sector as a way of understanding the importance of local information in an environment and a market that is decreasingly satisfied with the offerings of mainstream news providers. Numerous studies in the past 10 years have reported on the loss of quality, investigative information emanating from commercial news providers-the US State of the News Media Report has found that news organisations are offering thinner product, with fewer resources and fewer journalists each year

\section{Graph 1: Community Broadcasting sector growth 1984/85 - 2007/08}

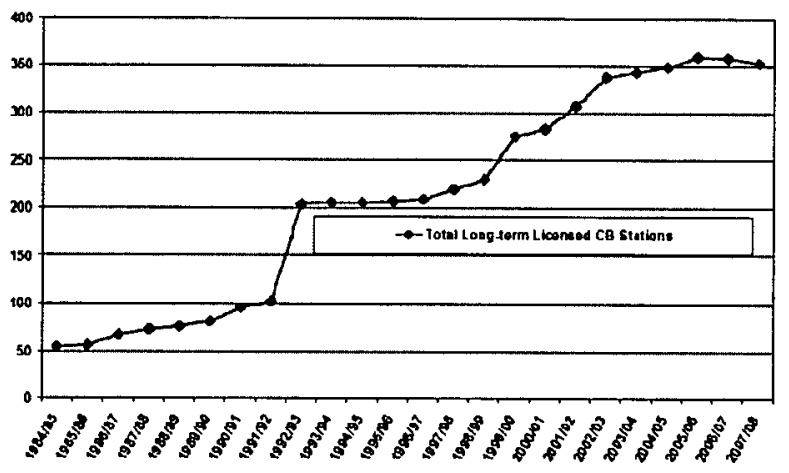

Source: McNair Ingenuity, 2008 
they conduct their study (Pew Center, 2004, 2005, 2006, 2007, 2008). The parallel Australian study, while not on the same scale as the Pew Center's effort has found an increasing influence on our news content from public relations firms and government 'spin doctors' (Australian Press Council, 2006), a finding which comes as no surprise to most practitioners. Bob McChesney's political economy analyses of US journalism finds poor quality is a 'rational result' of the overwhelmingly commercial structure of most news organisations (2003), and Nick Davies' revealing Flat Earth News (2007) exposes further the power of public relations in contemporary news and what he assesses as the falsehoods and propaganda peddled relentlessly by mainstream editors and some journalists. It is not surprising, then, that within this environment there has been increasing attention given to alternative media forms such as community radio and television (most recently, Lewis for the Council of Europe, 2008); citizens' journalism experiments such as blogs, Indymedia, and the Web Diary (Media Report, September 1, 2005; Platon and Deuze, 2003; Bolton, 2006); and other more familiar forms of independent and alternative media (Atton, 2002; 2003; Rodriguez 2001; Howley 2005; Gordon 2009; Atton and Hamilton 2008 among others). Elghul-Babawi suggests that while there is certainly a "blurring of the edges when it comes to defining alternative media', the blurring is itself an indication of the diversity of forms and practises that community, alternative, radical and grassroots organisations represent (2009, p. 21).

Research interest in this component of our media landscape-which has, until relatively recently been largely ignored by media scholars (Gordon, 2009, p. 12) - has undoubtedly been a response to the growth of these parts of the media industry which, in turn, has occurred due to an increasing gap being left by mainstream offerings. Howley (2005, p. 30) asserts that these 'locally orientated, participatory media organisations are at once a response to the encroachment of the global upon the local as well as an assertion of the local cultural identities and socio-political autonomy in the light of these global forces'. He further asserts the contribution of community media to a 're-coupling' of community 'within which practitioners and audiences might engage' (in Atton, 2003, p. 268). Indeed, audience research into the Australian community media sector finds strong evidence for a model of cooperation between audience members and their valued community broadcasting outlets-and an overwhelming sense of 
'empowerment' that audience members are offered by such community media forms (Meadows, Forde, Ewart, Foxwell 2007a, pp. 10-11; and Meadows et al, 2007b, p. 35).

\section{Method}

This article draws on data collected over nine years from the Australian community broadcasting sector. Through a combination of quantitative surveys and qualitative interviews with community radio station managers, journalists and volunteers; and a series of 48 nationwide focus groups with community broadcasting audiences, this paper aims to provide an understanding not just of what community broadcasting is providing in terms of news and information; but how they are providing it, how their audiences perceive it and-most importantly - why audiences want it. We have provided a case for the research methods we have used in other fora (see Meadows, Forde, Ewart, Foxwell 2005; and Forde, Meadows, Ewart, Foxwell 2006); and generally have complemented quantitative surveys conducted in 2001-2002 with journalists and news programme volunteers with qualitative focus groups for community broadcasting audiences in 2004-2006. The original quantitative surveys were based variously on previous work in Australia by Henningham (1992; 1996); Schultz (1994) and Forde (1997; 1999); and internationally by Weaver \& Wilhoit's established surveys of US journalists (1986; 1994; 1996; 2002). Our qualitative study, which combined audience focus groups across Australia with 'key person' qualitative interviews enabled a much deeper understanding of the practises and purpose of community broadcasting. Importantly, the focus groups included nine audience groups drawn from various ethnic communities; and a series of wide-ranging focus groups and semi-structured group interviews with Indigenous audiences.

Note this article will also refer to and draw upon data from a 'quantitative audience study' and this should not be confused with the original research we have conducted - the quantitative audience study refers to the national surveys of community broadcasting audiences, financed by the Community Broadcasting Association of Australia and conducted by McNair Ingenuity.

\section{Community broadcasting audiences}

In quantity, the community radio sector in Australia is far bigger than the commercial radio sector which contains about 270 licensees, but in 
financial terms, the commercial radio sector absolutely dwarfs its community cousin - funded by an estimated $\$ 12$ billion (Schulze \& Sainsbury, 2006) while the entire community radio sector operates on a total annual budget of just under $\$ 51$ million (CBOnline Survey, 2007). And yet, we find that community broadcasting produces more local content, plays more Australian music and supports a greater diversity of Australian cultures than any of their commercial counterparts. Data released in late 2008 by McNair Ingenuity, a research consultancy regularly contracted by the Community Broadcasting Association of Australia to conduct quantitative audience studies, has indeed found that audiences for community broadcasting are increasing. In 2004, the first year the McNair Ingenuity figures were collected, 40 percent of Australians listened to community radio at least once a month. At that time, 24 percent listened to community radio at least once a week (McNair Ingenuity, 2004). By 2006 those figures had increased-monthly listening was up to 47 percent of the population; and weekly listening had increased slightly to 25 percent of the population. The most recent figures, released in 2008 , show further increases-monthly listening is up considerably so that 57 percent of Australians now tune in at least monthly to a community radio station; and 27 percent tune in weekly (McNair Ingenuity, 2004; 2006; 2008). Significantly, each survey reveals that the main reasons why audiences listen to community radio are to hear specialist music; and to hear local news and information that they cannot access anywhere else. More than 53 percent of those surveyed in 2008 indicated local news and information was the key reason they tuned in to community media. Importantly, exactly one-third of audience members also nominated 'They give an independent voice/They're not owned by big business or government' as one of the other primary reasons for listening, which provides additional impetus for the importance of the 'different' information that community radio is equipped to provide.

These quantitative figures have served to confirm what our study discovered in its qualitative audience study, particularly in terms of the importance that audiences place on the provision of local news and information. Indeed, in the more than 350 hours of recorded focus groups and interviews that we conducted, the provision of local news and information was one of five key findings or 'reasons for listening'. It makes sense that people would listen to community media to hear 'community' or local information - but it is certainly useful to have that perception borne out by both quantitative and qualitative 
Graph 2: Percentage of Australians ilstening to community radio

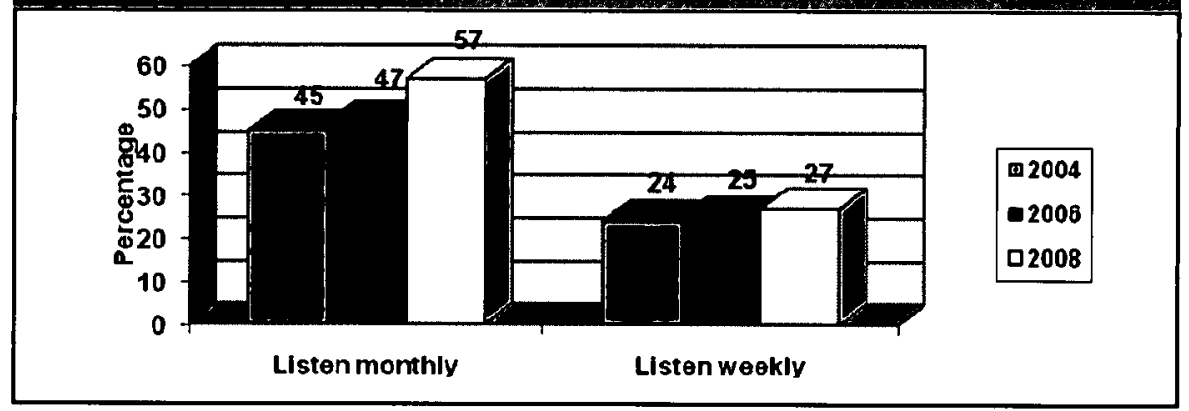

Source: McNair Ingenuity

research. Further, the more-than 25,000 volunteers who converge on their local community radio station each week around Australia do so to maintain their communities of interest; to establish dialogue with audiences, and to provide local information and culture, among other things (Forde, Meadows, Foxwell, 2002b, p. 65; 2002a). One volunteer from our Albany focus group in 2001 which involved station managers and volunteers offered:

...I can go from one day to the end of the next week and not watch television or watch the news... for me in the short term, I'm not really fussed what's happening out in the world. I'm sort of fussed about what's happening here, locally, because that's what effects me day to day...you see it on the news about globalisation, I think people are getting tired of that, they want to come back to home and find out what's happening in their backyard (Albany Focus Group, 10/09/01).

The participation of citizens in their local media and their commitment to addressing and raising the profile of issues in the local area sets community radio apart from public and commercial media networks. The $2006 \mathrm{CBOn-}$ line survey found 25 percent of community broadcasters in regional and rural Australia were the only providers of local content; and if this category is narrowed further to rural only, the figure jumps to 38 percent of rural community broadcasters who are the only provider of local content in their area (CBOnline, 2007). And their audiences are acutely aware of the commitment of community broadcasters to their local communities. We conducted audience focus groups with three major sectors of the Australian community media - generalist metropolitan and regional radio and television; 
Indigenous radio and television; and full-time and part-time ethnic broadcasters. Consistently, across all three audiences, the provision of news and information directly relevant to these communities was cited as one of the primary reasons for listening (Meadows et al, 2007, p. 1-2).

\section{Defining news in a community media setting}

The local news and information role of community radio stations does require some negotiation around definitions of 'news and information' and in particular, the format in which it is broadcast. Our research supports a broad definition of local 'news and information', which includes information about local music or cultural events, not necessarily within a formal news bulletin. The challenge to mainstream definitions of 'news' or more accurately, 'newsworthiness' was discussed at the Bay FM focus group:

Participant 1: But you see it depends how you define news, like I think, the news about the arts, the news about, I mean, music that's news, arts is news, some theatre is news. Like news isn't just, you know, bombs went off in London or the football. I mean we don't have to listen to endless shows about football or cricket. I mean, it is your definition of news. There's a lot of news on it but it's not necessarily the way it can be defined on other stations.

Participant 2: It keeps you informed about so much that's going onkeeps you up to date you get so much depth from it, it's very, very informative.

Participant 1: Lost dogs, CDs stolen out of someone's car, someone's pinched Sean's bike again! (Focus Group, Bay FM Byron Bay, 2005).

In our first station-based study of the community radio sector, we found that one-fifth of stations were not producing any form of local news service at all (Forde, Meadows \& Foxwell, 2002a, p. 83). Of the 80 percent of stations that did broadcast a news service, two-thirds of those were broadcasting a syndicated service. We were disheartened by these figures initially as we had expected a significant commitment within the sector itself to broadcasting local news and information. Indeed, discussions with community radio representatives and policy officers in 1999 and 2000 indicated the delivery of news and information was not one of its primary goals. However, we found that while ours and the sector's definition of 'news'-a dedicated news bulletin, current affairs show, hourly updates etc-was not widespread across 
the sector, news and information is provided throughout different programs in the general course of their delivery and through dedicated community announcements. As reported elsewhere (Meadows et al, 2009, p. 161), this finding from 2002 was borne out by comments from audiences in 2006-07:

The local news component on Radio Nag comes through the programs, because most programs have news and information in them and they tell you what is happening locally. It is about local stuff that is happening here that you hear in each of the programmes. The groups that present programs like RSL and Land Care talk about what is happening locally too. It is in-depth information and a wide source of information about the community (Focus Group, Radio Nag Yeppoon, 2005).

Audiences have told us they do not need to hear an hourly news bulletinthey simply want information about a range of issues and events from their local area.

I mean I don't want to listen every hour that somebody has been charged with murder or somebody has been raped or you know the London things. I mean that's what I am trying to get away from, I'm sorry. So if we define that as news, I'm glad it's not on Triple R (Focus Group, 3RRR Melbourne, 2005).

It is important to consider that the dominance of local news in the sectorand indeed the clear desire from audiences for primarily local news and information-suggests that the sector is not, at the moment, well-equipped to address the gaps being left by mainstream media in quality and investigative journalism. While community radio is filling the gap left by commercial organizations that have abandoned rural and regional areas due to cost-cutting decisions, the fact that few community radio stations produce their own news and current affairs would suggest that investigative news is not one of its main services. Certainly, particular stations such as Radio Adelaide; $4 \mathrm{ZzZ}$ in Brisbane; 2SER based at the University of Technology Sydney; and 3CR in Melbourne are producing quality alternative news which is attempting strong investigative work. Additionally, the sector's current affairs program The Wire provides good examples of strong news work and some investigation; while the Indigenous sector's CAAMA News and National Indigenous News Service also provide regular and original news content for their networks. 
On the whole, however, our research would indicate that the sector's strength - aside from these stand-out examples - is in its provision of local news and information which may vary in nature from local environmental and social issues right down to the 'social glue' local activities-announcing the time and place for the next community dance, morning barbeque, or local show.

Indeed, when community radio stations do produce their own news-and this occurs in about 26 percent of stations - that news is overwhelmingly committed to local information and news. This suggests that while the majority of community radio stations syndicate their state or national news service, they identify their own news production as having the potential and responsibility to provide a unique and informed local service. Almost three-quarters of the community media sector's journalists said their station's most important role was to provide local news and information - unfortunately it was resources, more than will, that often saw this role unfulfilled by many stations. When they did provide news, community media news producers were convinced their content was offering something significantly different to mainstream news providers. Community radio news journalists and producers suggested:

Our role is filling in the gaps left by censorship in the mass media. We are a voice for people and issues, and music that isn't presented elsewhere.

[Our role is] to be the voice of the voiceless-to give access to people who have no access to other media.

We are more culturally sensitive to the issues. We don't sensationalise as much and don't insult any groups or culture.

We do everything different. The mainstream media doesn't cover certain things AT ALL. There is no coverage of environment issues, or really no depth to the coverage. We provide more than a 30 -second grab, we give background and more information.

Our ability is to inform people who have no other access to mainstream media. We're correcting mainstream media myths-providing options and different sides to stories.

If we couple, then, the findings from audiences which identify a broad definition of 'news' with these findings from producers and journalists, we can suggest that not only the audiences but the producers as well are defining news in quite a different way in the community context. If only one-quarter of 
community radio stations are offering a dedicated news program, but around 69 percent have said they offer local news and/or current affairs (Forde et al., 2002a, p.86) then a large number of stations are producing news and current affairs content outside the usual news/current affairs dedicated program. Like their audiences, producers in the sector are also therefore applying a broad definition to what constitutes news on their stations and it usually comes in the form of on-air discussions with local environmental groups, visiting politicians, and cultural figures as well as talk back programming and general community announcements about both cultural and political activities in the local area.

\section{Conclusion}

Community broadcasters in Australia-both radio and television, although primarily radio - are not producing original, traditional news content in large volumes. Indeed, only about one-quarter of Australian community radio stations offer their own original news service. Importantly, though, both the quantitative and qualitative data indicates that our definitions of news do not necessarily apply in the community context-particularly for audiences, the provision of local information about cultural events, sport, festivals, visits from VIPS and social events is considered essential local news. It usually comes in the form of community announcements, or discussions which emerge between announcers and guests throughout the course of the program and is not presented as a formal news bulletin. Audiences were indifferent to this - they apparently did not need to hear specific news bulletins on their community radio stations but emphatically wanted to hear local news and information across the day and in a variety of formats. The local news and information role of community radio is valued by their audiences, particularly in regional areas. Metropolitan audiences have other news sources and do not rely so heavily on community radio for their news. This does not suggest that news services on metropolitan stations are unimportant-but more that traditional definitions of news and newsworthiness need to be negotiated in the context of the community media sector. Audiences are quite attuned to the concept that the definition of 'what is news' can and should go well beyond the traditional journalistic boundaries that we might normally identify as 'news' and it is this broad type of local news and information that they are looking for. One of the few other completed community broad- 
casting audience studies, conducted in The Netherlands and funded by The Netherlands government, also found that 'local news' was the primary reason audiencesnominated forlistening tocommunity radio and watching community television-it was even more significant than music programming (Council of Europe, 2008, p. 23). This suggests that while we might expect commercial radio listeners are primarily listening for music formats and content - and music programming is indeed important in the community sectorit is significant that community radio's news content is, usually, the main attraction for audiences. The primary issue is that this news delivered by community broadcasters is produced in a variety of formats-talk back; interview-based programs; community announcements; and news bulletinsall of which fall within the audience's definition and understanding of 'news content'.

This article began with a discussion of the shortcomings of mainstream news programs which is a common theme among much current media research particularly emanating from scholars interested in the future of journalism. The findings of our research into Australian community media over the past nine years indicate that the mainstream is, indeed, letting down a variety of Australian communities-geographical, communities of interest, and ethnic communities-in its provision of local news of interest to them. Fortunately, this gap is being filled by the growing community media sector which, while generally not offering dedicated news services due to resource limitations, is certainly fulfilling its overriding commitment to provide information of relevance to its community of interest. It does this by employing simple definitions of news and engaging members of the local community in on-air discussions about upcoming events, politics and social concerns. This model of 'journalism', or more accurately, news provision, sits more closely with newer forms of citizens' journalism and audience-driven journalism than the traditional formats of news production.

\section{References}

Atton, C., and Hamilton, J. (2008). Alternative journalism. London: Sage. Atton, C. (2003). What is alternative journalism? Journalism, 4(3), 267-272. Atton, C. (2002). Alternative media. London: Sage.

Australian Communications and Media Authority. (2008). Community broadcasting licences-Feb 2008. Retrieved 15/9/08 from, www.acma.gov.au/webwr/assets/ main/lib100052/lic031_community_radio_broadcasting_licences.pdf 
Australian Communications and Media Authority. (2008). Community broadcasting TCBL-June 2008. Retrieved 15/9/08, from www.acma.gov.au/webwr/_assets/main/ lib100052/lic027_current_tcbls.pdf

Australian Press Council. (2007). State of the news print media in Australia: A supplement to the 2006 report, Sydney: Australian Press Council. Retrieved July 15 2008, from www.presscouncil.org.au/snpma/index snpma2007.html

Australian Press Council. (2006). State of the News Print Media in Australia, Sydney: Australian Press Council. Retrieved July 15 2008, from www.presscouncil.org.au/ snpma/snpma_index.html, Sydney: Australian Press Council.

Bolton, T. (2006). News on the net: A critical analysis of the potential of online alternative journalism to challenge the dominance of mainstream news media. Scan, 3(1). Retrieved on 12 August 2006, from http://scan.net.au/scan/journal/display. php?journal_id $=71$

CBOnline, Community broadcasting database : Survey of the community radio sector, 2005-06 Financial Period, CBAA, Sydney, December 2007. Retrieved on February 20 2008, from www.cbonline.org.au/index.cfm?pageId $=37,0,1,0$

Davies, N. (2007). Flat earth news, London: Random House.

Downing, J. (2001). Radical media: Rebellious communication and social movements. Thousand Oaks: Sage.

Elghul-Babawi, S. (2009). The relationship between mainstream and alternative media: A blurring of the edges? In J. Gordon (Ed.), Notions of community: A collection of community debates and dilemmas, (pp. 17-32). Bern: Peter Lang.

Forde, S., Meadows, M., Foxwell, K. (2006). The untapped potential of participation: Evaluating audiences in the Australian community radio sector, Australian Studies in Journalism, 16, 74-100.

Forde, S., Meadows, M., Foxwell, K. (2002a). Culture, commitment, community : The Australian community radio sector, Final Report. Brisbane, Griffith University. Available at www.cbf.com.au/Content/articlefiles/43-culture_committment community_part_a.pdf and www.cbf.com.au/Content/articlefiles/culture_committment_community_part_b.pdf

Forde, S., Meadows, M., Foxwell, K. (2002b). Creating a community public sphere : Community radio as a cultural resource. Media International Australia, 103, 56-67.

Forde, S. (1999). Journalistic practices and newsroom organisation in the independent and alternative press. Australian Journalism Review, 2l(4), 60-79.

Forde, S. (1997). Characteristics and ethical values of Australia's independent press journalists, Australian Studies in Journalism, 6, 104-126.

Gordon, J. (2009). Introduction. In J. Gordon (Ed). Notions of community : A collection of community debates and dilemmas (pp. 11-14). Bern: Peter Lang.

Henningham, J.P. (1996). Australian journalists' professional and ethical values, Journalism and Mass Communication Quarterly, 73(1), 206-218.

Henningham, J.P (1992). Results from national survey of journalists, raw data provided to author.

Howley, K. (2005). Community media people, places and communication technologies. Cambridge: Cambridge University Press. 
Lewis, P. (2008). Promoting social cohesion : The role of community media, Strasbourg: Council of Europe.

McChesney, R. (2003). The problem of journalism: a political economic contribution to an explanation of the crisis in contemporary US journalism. Journalism Studies, 4(3), 299-329.

McNair Ingenuity Research. (2008). Community radio national listener survey-Summary report of findings. Retrieved on July 152008 from www.cbonline.org.au/ media/McNairListners2008/FullNationalListenerSurvey2008.pdf

McNair Ingenuity Research. (2006). Community radio national listener survey-Summary report of findings. Retrieved on May 30, 2006, from www.cbonline.org.au/ media/monair_survey_06/McNair_Report.pdf

McNair Ingenuity Research. (2004). Community radio national listener survey-Summary report of findings. Retrieved on June 18 2005, from www.cbonline.org.au/ media/mcnair_survey_04/McNair_Report_2004.pdf

Meadows, M., Forde, S., Ewart, J., Foxwell, K. (2009) Making good sense : Transformative processes in community journalism, Journalism, 10(2), 155-170.

Meadows, M., Forde, S., Ewart, J., Foxwell, K. (2007a). Community media matters: An audience study of the Australian community broadcasting sector. Brisbane, Griffith University. Retrieved on May 10 2007, from www.cbonline.org.au/index. cfm?pageId $=51,171,2,0$

Meadows, M., Forde, S., Ewart, J., Foxwell, K. (2007b). Empowering audiences: Transformative processes in Australian community broadcasting, Australian Journalism Review, 29(1), 27-39.

Meadows, M., Forde, S., Ewart, J., Foxwell, K. (2005) Perfect match? Qualitative audience research and the community media sector, $3 C$ Media Online, www. cbonline.org.au $/ 3 \mathrm{cmedia} / 3 \mathrm{c}$ issue $1 /$ index.shtm

The Media Report, Radio National, September 1, 2005. Margo: Unplugged retrieved from http://www.abc.net.au/rn/mediareport/stories/2005/1449823.htm, June 30, 2006.

Pew Project for Excellence in Journalism. (2009). The State of the News Media: An Annual Report on American Journalism, published by the Pew Center. Retrieved on 27 April 2009, from www.stateofthemedia.org/2009/index.htm

Project for Excellence in Journalism. (2008). The state of the news media : An annual report on American journalism, published by the Pew Center. Retrieved on 20 June 2008, from www.stateofthemedia.org/2008/

Project for Excellence in Journalism. (2007). The state of the news media: An annual report on American journalism, published by the Pew Center. Retrieved on 20 June 2008, from www.stateofthemedia.org/2007/

Project for Excellence in Journalism. (2006). The state of the news media: An annual report on American journalism, published by the Pew Center. Retrieved on 18 August 2007, from www.stateofthemedia.org/2006/

Project for Excellence in Journalism. (2005). The state of the news media: An annual report on American journalism, published by the Pew Center. Retrieved in April 2006, from www.stateofthemedia.org/2005/ 
Project for Excellence in Journalism. (2004), State of the news media, 2004. Retrieved from on 10 August 2004, from www.stateofthenewsmedia.com/2004

Platon, S., and Deuze, M. (2003). Indymedia journalism: A radical way of making, selecting and sharing news? Journalism, 4(3), 336-355.

Rodriguez, C. (2001). Fissures in the mediascape: An international study of citizens media. Cresskill: Hampton Press.

Schultz, J. (1994). Media convergence and the fourth estate. In Schultz. J (Ed.), Not just another business. Monash University: Pluto Press.

Schulze, J., and Sainsbury, M. (2006). Kerry Stokes joins media frenzy. Australian, October 18.

Weaver, D., Beam, R., Brownlee, B., Voakes, P., and Wilhoit, G.C. (2002). The face and mind of the American journalist. Florida: Poynter Institute.

Weaver, D. and Wilhoit, G.C. (1996). The American journalist in the 1990s : US newspeople at the end of an era. New Jersey: Mahwah.

Weaver, D. and Wilhoit, G.C. (1994). Daily newspaper journalists in the 1990s. Newspaper Research Journal, 15(3), 2-21.

Weaver, D. and Wilhoit, G.C. (1986). The American journalist : A portrait of US news people and their work. Bloomington: Indiana University Press.

Dr Susan Forde teaches journalism at the School of Humanities, Griffith University and worked as a print journalist before entering academia in 1998. Her recent research with Griffith University colleagues on community broadcasting audiences rounds out her research interest in all forms of independent and alternative media. Her research focuses on the journalistic practices of independent, alternative and community media journalists and recent research couples this interest with audience perceptions of news and journalism.

The author wishes to gratefully acknowledge the contribution of her colleagues Michael Meadows, Kerrie Foxwell and Jacqui Ewart to the research projects which have formed the basis of this article.

s.forde@griffith.edu.au 
Copyright of Pacific Journalism Review is the property of Auckland University of Technology and its content may not be copied or emailed to multiple sites or posted to a listserv without the copyright holder's express written permission. However, users may print, download, or email articles for individual use.

http://www.aut.ac.nz/depts/commstud/journ/pjrsubs.shtml 